Article

\title{
"Sot's Skull Subsiding, Sweet Nothingness Betide Me": Suttree and Sartrean Bad Faith
}

\author{
Elijah Guerra \\ Department of English, Texas State University, San Marcos, TX78666, USA; eag76@txstate.edu \\ Academic Editor: Krzysztof Ziarek \\ Received: 28 March 2017; Accepted: 31 May 2017; Published: 5 June 2017
}

\begin{abstract}
Cormac McCarthy's Suttree is a literary representation of existentialism. The eponymous protagonist seeks his meaning and purpose in a universe that offers none. Jean-Paul Sartre's existentialism proposes that people must fill the blank slate of the self and establish their own values through their actions. However, instead of establishing his values according to his constantly becoming self, Suttree restrictively bases his values on his material, monetary, functional and social existence. Sartre's theory of bad faith provides a means to understand Suttree's identity conflict and argues that the individual should identify not with any particular state of being, but rather with the constant process of becoming. Bad faith is a mode of self-deception in which one believes he is something he is not, or believes he is not something that he is. Suttree's many forms of bad faith-material, monetary, functional, and social—hinder his ability to live a more meaningful and fulfilling life and embrace his responsibility to create himself. Of all the forms of bad faith Suttree suffers, perhaps the most detrimental to his project of self-creation is his failure to let go of the past. His obsession with past failures and deaths impedes his progress to a new, productive self. By transcending his oppressive past and realizing that he is a combination of his constituent parts and never solely one of them, Suttree understands his responsibility to embrace his past and propel himself into new identities in the constant quest of becoming. Suttree exemplifies a responsible embrace of the project of self-creation in the midst of materialism and nihilism.
\end{abstract}

Keywords: Suttree; Cormac McCarthy; existentialism; Jean-Paul Sartre; bad faith

\section{Introduction}

Cormac McCarthy's novels abound in philosophical wonder at life's mysteries. His characters wrestle with ancient questions about reality, life's meaning, human fate, morality, and identity, all while drafting answers both classic and innovative. Take the philosophical musings of the judge in Blood Meridian (1985) who posits that "[b]efore man was, war waited for him" (McCarthy [1985] 1992, p. 259); take Martha's fortitude in The Gardener's Son (1996) when she asserts that "[o]nce people are dead they're not good nor bad. They're just dead" (McCarthy [1996] 2015, p. 94); and take Suttree, the eponymous protagonist, who surveys the entirety of his life and probes every detail for the speck of meaning each moment contains. Suttree (1979) (McCarthy [1979] 1992), McCarthy's longest and most autobiographical work, is the apotheosis of the author's existential fiction. The novel is a literary filmstrip of Suttree's despair and subsequent reordering of his life. This story is not only a hyper-imagistic glimpse of Suttree's wade through a town and life of waste, but also an insightful recording of one man's psychological distress and his progression toward resolving his bad faith, which I will cover soon, and recovering self-authorship. Suttree, with its humorous yet grave episodes and its existential density, blends the art of literary fiction, which tells tales, with the art of philosophy, which relentlessly asks why.

Suttree is an ideal character for existential examination. His weighty reflectiveness and willingness to plunge into the unknown when answering questions such as who am I? and why am I here? not 
only impress the reader with his contemplative manner, but also exemplify a healthy curiosity for finding oneself and one's place in the world and human society. Furthermore, Suttree reveals a mode of being that is universal and problematic, one which deserves significant attention for its prominence and importance in human existence: Sartrean bad faith.

In Suttree, the protagonist roams the 1950s Knoxville, Tennessee, as an itinerant soul plagued with guilt, loss, death, and the fruitless project to live a meaningful existence in a seemingly purposeless universe. ${ }^{1}$ Suttree fails at first to construct meaning and values in his life and instead over-identifies with individual components of his identity—such as his loss, his inevitable death, his material body, and his existence as perceived by others-as if these components did not form webs of interdependencies and contribute to a holistic identity. Jean-Paul Sartre's theory of bad faith provides insight into how Suttree struggles to realize his identity as a cohesion of complementary components, a realization that would let him decide to continue his life in an existentially responsible manner, remaining true to his past and dedicated to the continual formation of the person he strives to be. Suttree's ever-present cognizance of the tragedies that were his twin's stillbirth and his son's childhood death perpetuates his paralyzing guilt and prevents him from overcoming his bad faith and constructing himself according to the vision he has of his life and of all humanity. As a result of his obsession with his many losses, he directs his consciousness and his actions toward projecting loss and death rather than creating a productive and meaningful life. This perversion of his state of existence disrupts his experiences by convincing him he belongs to the dead instead of belonging to his own life. Suttree's eventual resolution of this inner conflict of bad faith demonstrates a unique way of overcoming the tendency to be what one is not and instead forge the future of one's life toward a positive and worthwhile end. By reasserting himself through his work, accepting parts of himself he considers past or grotesque, and purging his previous nightmares, Suttree paves his way to responsible self-creation. Furthermore, his efforts to focus away from abstract horrors and toward concrete situations, and his leave-taking from a decaying and confining place allow him the liberty of self-creation.

Suttree lives in despair as he roams Knoxville in purposelessness and works a minimal job that keeps him stationary and afloat in a murky Tennessee river. Without the integrity to resist the void of meaninglessness into which he sinks, he is burdened with the idea that pains him the most: death. The possibility of dying now and the certainty of dying at some point in time are tyrannical imaginings to which Suttree subjects himself, depriving his consciousness of the freedom to live in self-affirmation. His obsession with death seeps into his accompanying mirror image - the Othersuttree or Antisuttree-and becomes for him a self-negating definition, as opposed to a self-affirming definition.

Sartre's existentialism illustrates that one is responsible for defining oneself through affirmation, not negation. According to him, one must affirm one's life and assert one's freedom by filling the blank slate of oneself through every action. He maintains that "existence precedes essence," by which he means that one exists as a living human being without values or certainties and only by acting does one acquire values and knowledge. He states that "man exists, turns up, appears on the scene, and, only afterwards, defines himself ... . [A]t first he is nothing. Only afterward will he be something, and he himself will have made what he will be" (Sartre 2004, p. 345). Due to one's initial nothingness, ${ }^{2}$ Sartre proposes that "man is condemned to be free" and that "once thrown into the world, he is responsible for everything he does" (Sartre 2004, p. 350). Existentialism is an attitude the central value of which is

1 Richard Marius proposes that the name Cornelius Suttree "combines associations of Roman stoicism and the nineteenth-century East Tennessee humorous Sut Lovingood and the word 'tree' that implies the reaching towards life and sunshine" (Marius 1995, p. 4).

2 Vereen M. Bell, in analyzing the world of Suttree, succinctly summarizes the concepts of nothingness and existentialism by defining human as "part nothing-identified with matter and death, known only to a reptilian eye-brain-and part human; and the human part is real only to the extent that it is contrived" (Bell 1988, p. 83). 
freedom. Suttree constricts his freedom to live his life in a meaningful way when he forfeits himself to his past and his visions of death.

Much has been written on the relationship between existentialism and McCarthy's novels. ${ }^{3}$ The human condition Sartre and Albert Camus describe-that of despair, meaninglessness, nothingness, near-annihilating freedom, and grave responsibility-is in blaring alignment with the human condition McCarthy's fiction captures. His novels demonstrate that existentialism is not a theory, but a reality, one which urges for responsible self-creation and lucid awareness of oneself and the world in which one lives. Despite the scholarship focusing on McCarthy and existentialism, nothing extensive has been written about how Sartrean bad faith applies to the character of Suttree. Bad faith-essentially, the belief that I am what I am not, or that I am not what I am-is a condition with immediate ethical implications and emotional consequences. Sartre, with his concept of bad faith, addresses the problem of how to understand oneself, a significant theme in literature and philosophy. His analysis of the condition of bad faith exposes the process an individual undergoes when adopting contradictory beliefs concerning his/her identity. Furthermore, Sartre's theory provides a solution to the problem of bad faith, one which we can apply to fictional characters first-here, the character of Suttree-and then to our own lives. Observing the significance of bad faith to the character of Suttree illuminates the significance of bad faith to humanity in general. In addition to Sartre's notion of bad faith, his conception of literature- that literature is a means to disclose a certain aspect of the world and attempt to bring about a change in the world through this disclosure-reinforces the importance of the philosophical, existential perspective McCarthy adopts in Suttree. For Sartre, the prose-writer is committed to "action by disclosure," and realizes that being a writer means "to act in such a way that nobody can be ignorant of the world and that nobody may say that he is innocent of what it's all about" (Sartre 1993, pp. 14-15). McCarthy, with his careful depiction of a life in need of repair, achieves a disclosure of human despair and inspires within the reader a longing for self-reconstruction for the character and all of humankind.

\section{Sartrean Bad Faith}

Suttree is experiencing, in various and unique ways, bad faith. Bad faith, as Sartre presents it, is a mode of self-deception in which one is both deceiver and deceived, believer and non-believer in the truth hidden. For Sartre, "the essential problem of bad faith is a problem of belief" (Sartre [1943] 1956, p. 112). In bad faith, one may believe that one transcends the labels that can be applied to oneself. Additionally, in bad faith, one may believe that one objectively, concretely identifies with a label. In both cases, the individual is treating oneself as merely an object. In the first instance, one is an object of complete freedom and resists labels. In the second instance, one is an object collecting labels and resists the responsibility of being free. Sartre presents bad faith as the antithesis to good faith —or, sincerity - only to later demonstrate that bad faith and good faith are involved in almost the same project of self-negation. Sartre claims that "[g]ood faith seeks to flee the inner disintegration of my being in the direction of the in-itself" 4 and that "[b]ad faith seeks to flee the in-itself by means of the inner disintegration of my being" (Sartre [1943] 1956, p. 116). Basically, good faith involves believing that I am permanently a certain way, and bad faith involves believing that I am permanently no certain way, but both formulas conceive identity as existing unchangeably either as a transcendence or a facticity.

3 (Shelton 1990, Marius 1995, Prather 1995, Holloway 2002, Cosper and Cary 1996, Canfield 2001, Luce 2009).

4 Hazel Barnes, the translator of the version of Being and Nothingness used in this essay, defines the in-itself as follows: "Non-conscious Being. It is the Being of the phenomenon and overflows the knowledge which we have of it. It is a plenitude, and strictly speaking we can say of it only that it is" (Sartre [1943] 1956, p. 800). 
Sartre's discussion of bad faith is an insightful contribution to the modern synthesis of freedom and mind-body-materialism, ${ }^{5}$ where both concepts are often considered incompatible. If a person is purely physical, how can that person be free? Sartre demonstrates that human consciousness, through its processes of belief, enables one to exist in a constant mode of becoming rather than a fixed state. Thus, in engaging in my life's projects, and in fluctuating between good faith and bad faith, the most accurate definition of my being is that I am becoming.

Sartre presents several modes of bad faith, each of which involves the belief that one is constituted by something that one is not, or that one is not constituted by something that one is. From Sartre's examples, it is the situation of the woman on a first date who is responsible for making a decision on whether they have sex, yet denies her responsibility and postpones this decision, reducing their interactions to the immediate present and isolating their behaviors from the context they inhabit; bad faith characterizes the café waiter who limits himself to the functions and mannerisms of a waiter and denies that he is in fact only a representation of a waiter; it is the situation of the homosexual who does not admit he is a homosexual, guiltily conscious of the implications of his behavior yet unwilling to assume that portion of his identity; and bad faith is the condition the critic imposes upon the homosexual when the critic denies him the freedom to not be a homosexual and reduces him to an object fixed in a permanent state (Sartre [1943] 1956, pp. 96-109).

In all these examples, the agents are not being true to themselves, or are not letting other persons be true to themselves. There is no limit to the possible forms of bad faith, and Suttree is a novel that captures a vast array of these possibilities of existence. Encompassing a mere five years of Suttree's life, the novel unveils his cognitive tensions and displays his many forms of bad faith in all their astonishing and agonizing complexity. However, bad faith is only one theme in Suttree and only one aspect of the protagonist's internal conflict. This existential and psychoanalytic analysis of Suttree is meant to complement the several historical, sociological and psychological perspectives offered by McCarthy critics. As Forrest G. Robinson suggests in "Everything's Interesting: Cormac McCarthy and the Social Construction of Reality," McCarthy's works deserve to be contemplated with the philosophical maturity and humility that the works themselves demonstrate. Robinson articulates McCarthy's belief that "everything is meaningful only in relation to larger structures of understanding, which are in turn outgrowths of a universal craving for order" (Robinson 2003, p. 89). With this in mind, the order we crave in Suttree will hopefully lead to a larger system of unifying observations and theories that challenge us to reassess our understanding of human existence, freedom, identity and responsibility.

\section{Material Bad Faith}

By material bad faith, I am referring to when one over-identifies with one's physical body, thereby objectifying oneself and disposing of one's responsibility. Suttree suspends his responsibility to choose himself and his future similarly to how the woman on a first date suspends her responsibility. The woman, in an attempt to delay her decision, acts as if she and her date are objects existing without the emotional and cognitive context of their situation. She reduces their interactions to "what is in the present" and "to being only what they are": material objects frozen in position like a table and a chair. She extracts the qualities of the man's character from their situation as if he is in essence a nice man rather than what is probably true instead, that he is being nice in order to have sex with her. She "does not want to realize the urgency" of her situation because doing so will force her to decide something she is unable, or not ready, to decide (Sartre [1943] 1956, pp. 96-97). Like the woman who knows "it will be necessary sooner or later for her to make a decision", Suttree is aware of his responsibility,

5 Mind-body-materialism is the theory that the mind-consisting of the brain, neural pathways, neurons, and other biochemical components-is purely physical, like the body. It posits that a human being is composed completely of matter and that there is no such thing as a non-physical mind. 
yet continues to roam Knoxville in purposelessness. He denies himself any concrete direction and, instead, remains revolving around his past misfortunes and his present, local itineracy.

Suttree's occupation as fisherman inspissates his passivity, trapping him in a sterile economic cycle contingent upon a stagnant, waste-ridden river. Vereen M. Bell notes that Suttree commits little effort or resources to fishing, yet he interprets Suttree's "lack of volition" as "a form of receptiveness" in which he "[puts] life to the test, requiring, or allowing, it to prove its worth on its own terms." Rather than taking the first move, what he fears may be a wrong move, in deciding his life's significance, he chooses to see what significance it already possesses. Bell posits that in Suttree's quest to discover "what his life is fundamentally and whether in the midst of death there can be life to be affirmed", Suttree exercises a "negative capability" to resist affirming life before seeing whether, or to what extent, it affirms itself (Bell 1988, pp. 72-73). Just as the objectifying woman may discover, during her abstention from deciding, a telling sign of her date's true self, Suttree also waits for the appropriate moment to seize his life when he is familiar with the nature of life.

William Prather views Suttree's passivity differently, stating that it is a form of commitment. Prather believes that "Suttree is making a commitment simply by not committing himself: a continuing lack of commitment is a form of commitment" (Prather 1995, p. 111). Suttree seeks to know the person at the core of his existence, as Prather argues. In order to uncover his internal identity, he must cast off the layers of identity laid upon him by society.

In addition to delaying his responsibility, Suttree buries his responsibility in the material body's demands and the material landscape's daunting density. Sartre's objectifying woman identifies with her "inert presence as a passive object" as she perceives her and her date's bodies to be subject-less and without significance to their situation or their feelings (Sartre [1943] 1956, p. 100). She pretends not to notice his hand holding hers, resisting association with her body and emotions while drawing their attention to her sudden strand of thoughts. She renders her body an object that does not belong to the person she is. Suttree also objectifies himself, yet in his case, it is mainly with a hedonistic devotion to satisfying bodily desires. Through his constant drinking, he lives with excessive attention his body's cravings to the extent that he damages his responsibility. He bases a significant portion of his happiness on sexual fulfillment, as when he is living with Joyce and they constantly have intercourse until he lies in bed as a "depleted potentate" (McCarthy [1979] 1992, p. 390). With alcohol and sex, he diminishes his identity to a body driven by other physical objects and chemicals until the corresponding diminishment of consciousness occurs. Thus, it is in his moments of drunken misery that he is most like a "passive object" being controlled, damaged, and weakened by the poisons he has chosen.

Suttree associates with materiality to the point of being lost within the materiality of his environment. As he rows through a flooded river riddled with garbage, a dead pig, and even a dead baby, 6 "he felt little more than yet another artifact leached out of the earth and washed along" (McCarthy [1979] 1992, p. 306). Suttree's past nightmares become intermixed with the landscape of Knoxville, perpetuating his bad faith by leading him to focus his life on the past failures instead of his present responsibility to create himself. As David Holloway observes, "the commodity landscapes of Knoxville ... [are] the material source for those death visions that haunt the protagonist" (Holloway 2002, p. 116). Holloway focuses on "commodities" as they present the threat of objectifying experience "by the unprecedented extension of exchange value into all areas of human life" (Holloway 2002, p. 117).

6 This scene recalls McCarthy's short story "A Drowning Incident" (1960), in which a boy looks into the river and sees his baby pups floating dead in a sack, supposedly drowned by his father due to the family's inability to support more animals: Then with the gentle current drifted from beneath the bridge a small puppy, rolling and bumping along the bottom of the creek, turning weightlessly in the slow water. He watched uncomprehendingly. It spun slowly to stare at him with sightless eyes, turning its white belly to the softly diffused sunlight, its legs stiff and straight in an attitude of perpetual resistance. (McCarthy 1960, p. 3) 
Everywhere Suttree goes he encounters death and decay within the commodity landscape and the material landscape in general. On Market Street, he enters an atmosphere of "putrefaction and decay", and he walks through the markethouse "where brick the color of dried blood rose ... in demented accretion"; he perceives the market as a "lazaret of comestibles and flora and maimed humanity"; it is a place where the faces are "goitered, twisted, tubered with some excrescence" and the people have "[t]eeth black with rot, eyes rheumed and vacuous"; along the meat venders, "a calf's head rested pink and scalded on a tray" on "meatcounters shuffling up flies out of the bloodstained sawdust" and "[g]reat cleavers and bonesaws hung overhead and truncate beeves in stark abbatoir by cambreled hams blueflocced with mold" (McCarthy [1979] 1992, pp. 66-67).

His nightmares plague him not only through the commodity landscape but also through the material environment in general. He sees that out of the earth, "rhomboid and volute shapes of limestone jutted all brindled with mud like great bones washed out" (McCarthy [1979] 1992, p. 9); in his own room, "the candled woodknots shone blood red and incandescent like the eyes of watching fiends" (McCarthy [1979] 1992, p. 16); and his friend Jimmy Smith is death personified, the "slack yellow skin of his shoulders and chest so bloodless and lined that he appears patched up out of odd scraps and remnants of flesh" (McCarthy [1979] 1992, p. 21); he cannot help but see a group of poker players killing time as they wait for death, "posting time at cards prevenient of their dimly augured doom" (McCarthy [1979] 1992, p. 22); he has a dream in which his brother approaches him with a knife in the street at night, saying "I have been looking for you" and holding onto Suttree with "his bone grip" (McCarthy [1979] 1992, p. 28); at the bus station, where he ironically goes to a purgatorial "waiting room," "[h]e marches darkly toward his darkly marching shape in the glass of the depot door" and sees his reflection as "[h]is fetch come up from life's other side like an autoscopic hallucination" (McCarthy [1979] 1992, p. 28). Throughout the novel, he refers to his reflections and shadows as the "Antisuttree", which is the self he believes should have died at his brother's death and the self he foresees dying. On workhouse duty cleaning the fairgrounds, Suttree sees "the stark skeletons of amusement rides against a gray and barren sky" (McCarthy [1979] 1992, p. 50); death watches him as when he shaves at the warehouse's spigot and "the cracked red clay lay shaped in a basin centered by a dark ocherous eye where the water dripped" (McCarthy [1979] 1992, p. 64).

Suttree is unable to escape his nightmares as long as he cannot transcend the material landscape in which he is fixed. According to Holloway, it is up to Suttree to solve the problem of being consumed by the commodity landscape in which "the existential fate of the self is to be immersed in a realm where the lines dividing human being from a world of animate and inanimate objects become blurred" (Holloway 2002, p. 117). Suttree, by means of his "existential gaze," rediscovers these dividing lines and is "saved from entrapment within the inertia of the commodity landscape" (Holloway 2002, p. 117). Suttree transcends the material world as his existential gaze "asserts the fragility of that commodity world, effecting what Sartre would call an existential 'going beyond' of the inertia in which matter traps human praxis" (Holloway 2002, p. 120).

Not only does Suttree face the difficulty of transcending the commodity landscape, but he also confronts difficulties when, being caught up in a market economy, he objectifies and monetizes himself and those around him. As Lydia R. Cooper suggests, in Suttree's constant exposure to market activities, "the physicality of the body becomes a consistent visualization that emphasizes ... the quality of commerce" (Cooper 2013, p. 193). Suttree, following the pattern of his environment, adopts a conception of himself and humanity saturated by monetary value, thus furthering his over-identification as a permanent object rather than a fluctuating subject. In Sartre's terms, Suttree's understanding of himself emphasizes the in-itself-non-conscious, physical being-and undervalues the for-itself-consciousness free to consider possibilities and negate current situations. As a result, Suttree becomes an object to be bought and sold, as when he becomes Joyce's possession and when his product as a fisherman is circulated through the town's market exchange. In order to live a meaningful and autonomous existence, Suttree must either reconcile his existential freedom with the 
material, deterministic system of Knoxville's market economy or assert his freedom by leaving the town altogether.

One's existence differs from the existence of objects mainly in that humans are conscious beings. Consciousness cannot be located as can a box of matches or a table. Therefore, the existentialist concludes, "I can not say either that I am here or that I am not here" (Sartre [1943] 1956, p. 103). Since consciousness resists location, identity similarly evades tendencies to identify with a certain place. To say that an individual identifies with a certain place is to risk restricting one's freedom and denying oneself the variety of identity - since identity consists of several things, not just the place with which one identifies; additionally, one risks denying oneself the possibility of identifying with new places and parting with old ones. Suttree denies himself the possibility of place by remaining in Knoxville, drowning in his nightmares. He perpetuates his obsession with his place by visiting certain locations that resurrect fond yet embittering memories. He visits the train yard, "remembering his grandfather stepping down to the platform among the wheeltrucks and the steam" and remembers "[t]he old man's cheeks new shaven and the fine red veins like the lines in banknote paper. His hat. His stogie." The inexistence of his grandfather and the past they shared is represented by the long-closed station with its "abandoned coaches" and waiting rooms turned storage houses (McCarthy [1979] 1992, p. 367). Suttree's sense of loss is inextricable from the condition of his surroundings, and his redemption depends on vacating Knoxville for a place in which he can create new and happier memories.

What saves Suttree from an unproductive passivity in which he evades the responsibility to create himself is his realization that he is beyond the material world and more than just an inevitable addition to the inanimate matter of the earth. He begins to see himself as a subjectivity rather than another object and therefore regains his will power and confidence in his own agency. As Holloway articulates Suttree's newfound ability to shape himself, "Suttree's own alienation [his sense of not belonging to the living world or to his own responsibility] within the practico-inert ... ceases to be something that merely happens and becomes instead the very proof of human praxis in the world at large" (Holloway 2002, p. 123).

\section{Bad Faith with Other People}

Bad faith is also possible in the dynamic between living as oneself and living as perceived by another human being. Sartre speaks of "a perpetual game of escape from the for-itself to the for-others and from the for-others to the for-itself" (Sartre [1943] 1956, p. 100). In the former, one is affirming one's existence as formed by the Other, and in the latter, one is affirming one's existence as formed by oneself. When Suttree is living with Joyce, he forfeits his freedom to form himself in exchange for Joyce's financial support. She provides him with a place to stay, a pretty car, new clothes, and fancy outings, all of which are made possible by her extravagant earnings from prostitution. Suttree takes this unstable lifestyle as his life's foundation and deprives himself of the ability to support himself. He is resting his identity in someone else rather than providing himself a foundation for his own existence.

Suttree's rejection of family relations is almost a reverse form of the bad faith he practiced with Joyce. Whereas with Joyce, Suttree gives her too strong of a grasp on his identity, with his family, he withholds from them credit for his identity. Suttree's family, like the blood that runs within him, is an unretractable component of who he is. However, he tries to avoid his family members as much as possible and resist their influence, limiting their claim on his identity. He has retained minimal ties with Uncle John, Aunt Martha, and his mother, nearly the only family members with whom he interacts in the entire novel. When Uncle John comes to visit Suttree at his riverside boathouse, Suttree struggles to acknowledge his own desertion of the family. He is resentful when Uncle John tries to remind Suttree of the characteristics he shares with other members. Suttree claims he is independent of his family members' influence and denies the part of himself that was born from those who raised him: "I'm not like you. I'm not like him. I'm not like Carl. I'm like me. Don't tell me who I'm like" (McCarthy [1979] 1992, p. 18). Similar to an actor who only identifies with one of his characters, 
Suttree only identifies with the aspects of himself that he desires and dismisses the aspects of himself associated with his family.

However, as Richard Marius argues, "[h]is passion for independence from his family is in itself a kind of bondage, for he can neither satisfy these expectations, accept family ties nor live truly indifferent to them as long as he remains in Knoxville" (Marius 1995, p. 8). Thus, Suttree's rejection of his family becomes a commitment that binds him to an active resistance of, and a contradictory concern for, those he wishes to remove from his life. Thus, it seems that his rejection of his family is both a source of freedom and captivity, the combination of which sustains and further complicates his bad faith.

\section{Attempts at Responsibility}

After a spell of delirious intoxication, Suttree has back-to-back dreams: in one, "a window full of glass somewhere collapsed in a crash" and he "heard pistolshots," a memory of his own involvement in the robbery that earned him workhouse time; the other is "[a] dream of shriving" in which "[h]e knelt on the cold stone flags at a chancel gate where the winey light of votive candles cast his querulous shadow behind him," and he "bent in tears until his forehead touched the stone" (McCarthy [1979] 1992, p. 78). Here, Suttree is lamenting his past mistakes. His shadow is at once the Antisuttree that premonishes his death, thickens his brother's absence, and accentuates his son's early decease.

Suttree cannot tolerate the unbearable weight of responsibility he feels for his son's death and the misery with which his wife is left forever. He is eager to claim full responsibility and relieve his guilt. After he hears of his son's death he goes to the son's family where he encounters his "abandoned wife," who is "grief-stunned," a "wooden pieta of perpetual doom"; his mother-in-law, a "demented harridan" with an "axemark for a mouth and eyes crazed with hatred"; and his father-in-law, "coming from the house loading a shotgun as he ran" (McCarthy [1979] 1992, pp. 150-51). To Suttree's one question "[w]hen is the funeral," the family rejects his involvement in the burial, thereby denying him the opportunity to claim responsibility and relieve his guilt.

Despite being prohibited from the funeral, Suttree forces his presence. As he looks on to the casket and the preacher, he "stood by a tree but no one noticed him" (McCarthy [1979] 1992, p. 153). After the funeral, he takes a shovel and fills the grave himself, despite being told by workers "[w]e got a tractor here to do that with" (McCarthy [1979] 1992, p. 155). By filling the grave, Suttree takes responsibility for his son's death, buries his guilt, and creates the bridge by which he will be able to cross the murky waters of his past. This moment is crucial in Suttree's formation of the self in that it begins his realization that the past cannot be used as the primary content for the self. Suttree must learn to perceive his loss as a hole that he is responsible for filling. In addition to burying the history that was Suttree's son, Suttree is also burying his own childhood. As Linda Woodson suggests, "it may be that Suttree's mourning is for two dead children, both the son and the child-self" (Woodson 2013, p. 187). She recalls how when walking to the funeral, he feels an anxiety similar to one experienced during his own past with his father: "The dread in his heart was a thing he'd not felt since he feared his father in the aftermath of some child's transgression" (McCarthy [1979] 1992, p. 152).

\section{From Negation to Affirmation}

Suttree stifles his self-creation by dwelling on the negative presence of his brother. He calls his brother the "[m]ore common visitor" and proceeds to recreate the image of his brother with "thin and brindled bones," a "bulbous skull," and "[o]n the right temple a mauve halfmoon." Suttree names the void left by his brother with identities such as "[t]he ordinary of the second son," "[m]irror image," "[g]auche carbon," "the child with whom you shared your mother's belly," and "[b]orn dead and witless" (McCarthy [1979] 1992, p. 14). Suttree grasps for some way to be in touch with his brother even if by his own imaginings. His mental reach toward death displays his longing to understand death and 
fit it into the narrative of life. However, in his effort to create a mental representation of his brother's void, he engages in a consuming process of negation to the detriment of his own self-affirmation.

In Being and Nothingness (1943), Sartre discusses the reality of absent objects as they exist in the form of non-beings. He provides an example in which he is to meet with Pierre in a café at four o'clock. Sartre arrives late and does not see Pierre. Thus, Sartre's expectation of meeting with Pierre "has caused the absence of Pierre to happen as a real event" (Sartre [1943] 1956, p. 42). Pierre's absence is a nothingness that is present in Sartre's consciousness, a negation of his expectations, and a void that he instead intended to be the presence of Pierre. Sartre constructs the idea of Pierre being absent, and this image engages in what he calls a double negation: "it is the nihilation of the world (since the world is not offering the imagined object as an actual object of perception)" and it is "the nihilation of the object of the image," since the Pierre imagined is not the actual Pierre (Sartre [1943] 1956, p. 62).

In the same way Pierre exists as a negation, Suttree's brother exists as a negation. Suttree expects his brother to be with him as he yearns for his presence and grieves his absence. To compensate for this absence, Suttree crafts his brother's presence through his imagination and dreams, visualizing "his brother in swaddling, hands outheld, a scent of myrrh and lilies"7 (McCarthy [1979] 1992, p. 113). It is by this act of consciousness that death is "what the living carry with them." Suttree keeps his brother's non-existence and reflects on his death despite its painful reality. The "state of dread" Suttree experiences is perpetuated but not relieved by imagining his brother (McCarthy [1979] 1992, p. 153). Vereen M. Bell articulates Suttree's recreation of his brother as "positing death as a vaguely existent entity ruling a dream world that is different from ours but also always present in it" (Bell 1988, p. 91). Consciousness is the point through which death and the dream world it rules can access Suttree's thoughts, but Suttree in part chooses to sustain the contact between the realm of the imagined dead and the realm of the living.

Suttree must learn to control or reconcile his deathly visions so these imaginings do not interfere with his self-creation. He must prevent the imagined dead from inspiring a paralyzing dread of his own death. Matthew Guinn perceives that Suttree's obsession with his dead brother "hinders his ability to achieve any sort of transcendence," and that "it is only by resolving his "subtle obsession with uniqueness' that Suttree can produce meaning within his atavistic surroundings" 8 (Guinn 2000, p. 112). Suttree's existential project of "transcending death" (Bell 1988, p. 69), as Bell puts it, and transcending the "struggle with nihilism" (Guinn 2000, p. 112), as Guinn states, depends upon his ability to incorporate these visions into an understanding of death's relationship to life and their mutual fulfillment.

As Guinn suggests, Suttree's nihilistic attitude weighs him down throughout his hardships, convincing him of the emptiness of life and the meaninglessness of existence. At the core of Suttree's bad faith is the negation of life and the nullification of himself rather than the blank slate of potential self-authoring. When talking with the sheriff after Suttree's son's funeral, Suttree claims "[n]o one cares. It's not important" (McCarthy [1979] 1992, p. 157). On returning to camp after he and Reese got lost he proclaims "[m]y life is ghastly" (McCarthy [1979] 1992, p. 348). Vereen M. Bell notes how "McCarthy's metaphysic" consists of "no first principles, no foundational truth" (Bell 1983, p. 32), which naturally leads to either the perception that nothing matters or that everything is possible. Bell argues that, although Suttree realizes "the true horror of death; the sure corruption and end of all friends, all love, all singular, cherishable things; the impersonal relentlessness of time; the cruel absence of God from the world," Suttree still decides that "a Suttree of the many possible in a world of antiform must be made to be" (Bell 1983, p. 40). Thus, when confronted with nihilism as represented by the ragman's death, Suttree sees the ragman's despair locked in a statuesque memorial to the

7 The scent of lilies recalls the same scent associated with Suttree's grandfather in a memory of him on his deathbed (McCarthy [1979] 1992, p. 13).

8 Guinn argues that Suttree and other of McCarthy's novels promote the conception of humanity as atavistic in nature, preserving an essential primitivism and depravity through all of time regardless of differing eras or cultures. 
negation of life, which leads him to reject the nihilist and his disintegrating attitude: "You have no right to represent people this way, he said. A man is all men. You have no right to your wretchedness" (McCarthy [1979] 1992, p. 422).

Edwin T. Arnold also sees Suttree's later actions as affirmations of life. According to Arnold, Suttree's statements that "there is one Suttree and one Suttree only" and that "[n]othing ever stops moving" (McCarthy [1979] 1992, p. 461) are ways of asserting "[a]ll things exist and have meaning" (Arnold 1999, p. 61). Arnold concludes that Suttree "has entered [the] world of the spirit and has acknowledged its power" and "has lost the terrible, incapacitating fear of death" (Arnold 1999, pp. 60, 61).

Although Arnold's position that Suttree has transcended death is true for a certain period of Suttree's life, it is unlikely that Suttree has conquered his fear in a final, determinate way. Since existentialism holds that the individual's every action shapes who he is, Suttree must maintain his transcendence throughout every day, and every action of every day, and so on. Suttree has learned that he is the author of his own attitude and that there are certain attitudes that favor his well-being and others that hinder his ability to live a fulfilling existence. The adoption of a nihilistic attitude is a choice to conform to the seemingly meaningless world in which one lives. Thus, the attitude forms an identity continuous with the condition of the world rather than being independent of such limitations. The existential mindset does not prefer a particular means of choosing one's identity over another means. However, the mindset Suttree assumes when departing Knoxville is an attitude seeking a unique identity that affirms its individuality and denies the negating forces of nihilism. Thus, Suttree's progress is not due to losing the fear of death as much as it is due to what Woodson suggests, which is that Suttree has stored "some of the images of his past in ways that will permit their recall without the intense accompanying pain of overwhelming emotion." She claims that "he is enabled to issue a dark warning to himself and to the reader because the fearful memory always comes unbidden in dreams" (Woodson 2013, p. 189). In this way, Suttree has preserved his past and stayed true to his narrative history without being consumed by the negating power of his loss.

\section{Responsible Self-Creation}

Suttree recovers from the internal slum of his non-responsibility and emptiness of self through his rediscovery of work. After parting with the prostitute with whom he made a temporary life until her mental breakdown and loss of patience, he returned to his houseboat where it "lay half sunken by one corner and the windows were stoned out and the front door was gone altogether." He cleaned the place, piecing glass for new windows and fitting a new door to re-establish his home. Finally, to restore the picture of his past, he places himself back in his practice as a modest yet stable fisherman:

He bought three five hundred yard spools of nylon trotline and spent two days piecing them with their droppers and leads and hooks. The third day he put out his lines and that night in his shanty with the oil lamp lit and his supper eaten he sat in the chair listening to the river, the newspaper open across his lap, and an uneasy peace came over him, a strange kind of contentment. Small graylooking moths orbited the hot cone of glass before him. He set back the plate with the dimestore silver and folded his hands on the table.

$$
\text { —(McCarthy [1979] 1992, pp. 413-14) }
$$

Suttree's newfound contentment issues from his reunion with his project of self-creation. He reclaims his title as author of himself and sets to work defining his life according to his work. No longer does he identify with the nothingnesses of the past. Instead, he aims his attention and efforts toward the occupation that will sustain his own life and the hobby that relieves the pains of existence. Life is restored its light, and despite the death inherent in the meeting of moth and flame, Suttree's self is alive, orbiting that into which he was thrown and of which he is an active creator. His hands and his will power sit above the wood of the world, folded one on the other as if to say "I have made myself."

His ensuing dialogue with himself raises the question "[o]f what would you repent," to which he answers "[o]ne thing. I spoke with bitterness about my life and I said that I would take my 
own part against the slander of oblivion and against the monstrous facelessness of it and that I would stand a stone in the very void where all would read my name. Of that vanity I recant all" (McCarthy [1979] 1992, p. 414). John Lewis Longley Jr., in "Suttree and the Metaphysics of Death" (1985), suggests that Suttree's answer to the question of his regrets is "the definitive statement of the Existential consciousness" (Longley 1985, p. 82). To expand upon Longley's idea, the "attitude" of existentialism, as Sartre refers to it, is an attitude of self-progression rather than self-pity or regret. Suttree is accepting his past including all failures and misfortunes as essential to his unique history. Upon this history he will build the remainder of his life.

Suttree also accepts the parts of himself he finds grotesque. As Lydia R. Cooper suggests, throughout the novel Suttree "externalizes himself through self-infantilizing imagery and self-referentiality" as he imagines himself as a child and has visions of the Othersuttree (Cooper 2013, p. 195). The Othersuttree partly refers to his dead twin but also refers to himself as he exists in the realm of the dead. Suttree's "dismembering gaze," as Cooper calls it, externalizes the aspects of himself that he is pained to accept. At the end of the novel, when he asserts "there is one Suttree and one Suttree only," he has come to the conclusion that the parts of himself with which he was afraid to identify-his dead brother and his own eventual death-are in fact essential components of his identity that when externalized change the self into what it is not (McCarthy [1979] 1992, p. 461). After Suttree's conversation with his double toward the end of the novel, he looks at the image and erases it: "Suttree's cameo visage in the black glass watched him across his lamplit shoulder. He leaned and blew away the flame, his double, the image overhead" (McCarthy [1979] 1992, p. 414). In extinguishing his double, he is incorporating it into the unity of his self and denying that it is separate from who he is. He realizes, as Cooper suggests, that "horror is necessary to a life made 'important'" (Cooper 2013, p. 197). In order to live meaningfully, Suttree must include all forms of himself in the coherent picture of his identity.

Suttree comes full circle and meets again the pigeons beneath the bridge from the beginning of the story: "He sat in back of the skiff and sculled it slowly down beneath the bridge. As he passed under he raised his head and howled at the high black nave and pigeons unfolded fanwise from the arches and clattered toward the sun" (McCarthy [1979] 1992, p. 415). Suttree's voice is newly born in an uproar for his own existence, and he lets loose the flock of freedom within himself and again sends it toward the light of life.

Suttree repossesses his self-creation through his cathartic purging of past nightmares under Mother She's hallucinogenics. The geechee witch prepares concoctions and unguents, pulling her supplies out of an "ageblackened box of boardhard leather" compared to a priest's "deathbed kit." He consults the witch for insight into his near future, but instead receives the answer "[t]o know what will come is the same as to make it so," harmonious with the existential approach of creating one's own future. To Suttree's question "[s]hould I go home" the witch answers "[i]t don't make no difference where you go," since where he should go is a lesser concern than who he should be. After the witch feeds him the prepared mystical recipe, "a door closed on all that he had been" and Suttree begins a sequence of dreams reaching into his past and highlighting the feelings he had in his family's Victorian style home in which "he knew ... some soul lay dying" (McCarthy [1979] 1992, p. 427). After his encounter with hallucinogens, Suttree wanders unstably home and finally, in his bed, "[h]e lay with his feet together and his arms at his sides like a dead king on an altar." Suttree laid his past nightmares down to die and made space within himself to form a new self. In his newly available and empty self, he is "floating like the first germ of life adrift on the earth's cooling sea, formless macule of plasm trapped in a vapor drop and all creation yet to come" (McCarthy [1979] 1992, p. 430). He has reverted back to a state of existence that precedes the essence he will form. As Bell notes, Suttree undergoes a filtering process in which he is "unmanned and dehumanized." Under the spells of Mother She, "[h]is body has been taken and rearranged; his self remains" (Bell 1988, p. 96).

Suttree's miserable bout of typhoid fever causes him nightmares that lead him to realize his life is unique and that he is responsible for evading death's reach. He parts with his Antisuttree in his declaration that "I am no otherbody." In his sick dreams, he meets the dead with whom he is "going out 
of the world" (McCarthy [1979] 1992, p. 452); he is at a courthouse on trial, accused of causing disorder in a clock shop, killing the shop's bird Tweetiepie, engaging in lycanthropy, and "[squandering] several ensuing years in the company of thieves, derelicts, miscreants," and other unvirtuous individuals; he comes across a turtle hunter in a forest path who stops Suttree, at which time Suttree realizes the turtles in his sack "are not turtles," but instead, humans; he sees a deathcart coming to pick him up; he sees God "unlocking with enormous keys the gates of Hades" and releasing "a floodtide of screaming fiends and assassins" (McCarthy [1979] 1992, p. 457).

From these dreams and delusions, he realizes that "there is one Suttree and one Suttree only." His near-death experience makes him aware that the Othersuttree, which he thought necessary for the completion of his identity, is not real and, therefore, is not a part of who he is: it is merely a mental construct that reflects his fear of death rather than a dead self parallel to his living self. Matthew Guinn notices that Suttree's affirmation of his singularity is a "refutation of the abstract construct that Suttree has sustained" and argues that this refutation allows him to "focus on the imminent [sic] instead of the abstract" (Guinn 2000, pp. 113-14). Through his reevaluation and projection of himself, Suttree learns that the real self is comprised of his physical body, his situation, and the decisions he makes. Suttree did not choose to be beaten down by typhoid fever, but he chose to emerge from his sickness with the will to recognize his uniqueness and focus on who he truly is.

Suttree's bad faith extends to his over-identification with the place in which he enjoys residing. McAnally Flats provides him a supportive community, but it is a community that occupies his time and governs the person he is. The destruction of McAnally Flats to build an expressway saddens Suttree, yet inspires him to move on to a different place. He observes the destruction of the flats as if some creature were being killed and torn open to reveal "[b]rickwork of dried bloodcakes in flemish bond crumbling in a cloud of dust" and "dead mortar," with "steel and pipes and old conduits reared out of the ground in clusters of agonized ganglia," leaving nothing but rubble, "rows of doors," and a "stairwell to nowhere" (McCarthy [1979] 1992, p. 464). The death of McAnally Flats leaves another hole in Suttree's life that he must fill by seeking a new place to live and starting again the project of self-creation. ${ }^{9,10}$

Suttree's rebirth is grotesquely yet artfully continued when he discovers a dead body resting in his home upon his return from the hospital. When he sees the man in his bed, he thinks a derelict slept in this home, believing it was unoccupied. Suttree takes the covers off the sleeping person and discovers a "foul deathshead bald with rot, flyblown and eyeless" (McCarthy [1979] 1992, p. 465). Suttree does not even attempt to rid the place of the dead body to restore his home to normal. Instead, he interprets the moment as the appropriate time to resettle elsewhere. The dead body furthers Suttree's dissociation from his home and motivates him to relocate himself and reform his identity. The death in his bed is like the death of the old Suttree and the closure of his home. ${ }^{11}$

At the end of the story, Suttree exits Knoxville and says goodbye to his home, his friends, and his past self. He leaves everything he owns in a secret spot and takes only "the simple human heart within him." In taking with him only his body, "there was nothing left of him to shed," and he departs on his journey like the Giacometti sculpture L'Homme qui marche I (1961), which displays a tall, slender man seemingly made of the earth itself and defined by no features except its own extension of limbs, head, and the will to walk (Giacometti 1961). He waits on the highway for a passerby to pick him up, and he watches a construction site nearby, a reflection of his own newly begun process of self-reconstruction.

9 Robert L. Jarrett argues that McAnally Flats is "the novel's objective correlative for Suttree's psyche," suggesting that its destruction is the birth of Suttree's reconstruction (Jarrett 1997, p. 54).

10 Peter Josyph posits, similarly to Robert L. Jarrett, that the destruction occurring in Knoxville is the same destruction occurring in Suttree. Josyph offers that when McCarthy tells Suttree "Uneasy sleeper you will live to see the city of your birth pulled down to the last stone" (McCarthy [1979] 1992, p. 188), "he is talking about the cavernous city of Suttree himself" (Josyph 2010, p. 9).

11 Longley claims that this scene means "death has come for Suttree and has found someone else instead" (Longley 1985, p. 89). I believe that if Death is a force with a "mathematical certainty," (McCarthy [1979] 1992, p. 295) then it makes no mistakes. It knows who it comes for, where they are to be found, and for whom it is time to die. This scene represents death as it functions in Suttree's rebirth rather than in his missed death. 
When the construction crew's water boy comes over to Suttree to give him a drink, Suttree looks into the boy's eyes, in which he "beheld himself in wells of smoking cobalt, twinned and dark and deep in child's eyes, blue eyes with no bottoms like the sea"12 (McCarthy [1979] 1992, p. 471). This is the last reflection of himself that Suttree encounters in the story. Instead of the deathly reflections he faced previously, now he sees unlimited, oceanic possibilities for a new self.

When a car picks him up, Suttree takes one last look behind him and sees that "the city lay smoking, the sad purlieus of the dead immured with the bones of friends and forebears." What Suttree once knew is now a pile of dead matter he transcends. He denies the paralyzing grip of grief over lost loved ones and chooses instead to reach for new relationships and occupations. He looks at the expressway under construction "where the ramp curved out into empty air and hung truncate with iron rods bristling among the vectors of nowhere," a structure similar to his own self, the making of which now resumes (McCarthy [1979] 1992, p. 471).

Suttree sees that where he had previously stood hitchhiking on the highway was now "[a]n enormous lank hound," the companion of whom is the huntsman, Death, whose "work lies all wheres and his hounds tire not." Suttree's dreams contained these hounds, "slaverous and wild and their eyes crazed with ravening for souls in this world." He dismisses the hound with the imperative "[f]ly them," and with his fleeing he claims his freedom from death and his resistance to its nullifying presence and reminders (McCarthy [1979] 1992, p. 471).

Suttree is conscious that he is a representative of all humanity in his sufferings, labors, and moments of transcendence. By choosing to come to terms with his past and move on to another part of the world, he asserts his view of what a human should be: resilient, determined, and above the past. Sartre's existential attitude not only posits that "man is responsible for himself" but also argues that "he is responsible for all men" (Sartre 2004, p. 346). Suttree's self-reconstructive actions are aimed at reconfiguring his conception of his own future, his conception of humanity, and his notion of how he fits inside the web of others' lives. He recognizes what Sartre poses when stating "in creating the man that we want to be, there is not a single one of our acts which does not at the same time create an image of man as we think he ought to be" (Sartre 2004, p. 346). Suttree chooses his values and the values he thinks best for humanity, as Sartre maintains that "[ $t$ ]o choose to be this or that is to affirm at the same time the value of what we choose" (Sartre 2004, p. 346). When he speaks over the dead ragpicker's body "[a] man is all men. You have no right to your wretchedness" (McCarthy [1979] 1992, p. 422), he recognizes that humanity as represented by the ragpicker is far worse off than the humanity represented by Suttree's newly formulated purpose.

Suttree's example is not restricted to the world within the novel. Rather, as Martha C. Nussbaum suggests in her argument that literature contains moral value, Suttree's self-affirmation and self-creation exemplify the way to live when readers find themselves in similar circumstances. Nussbaum claims that "a responsible action ... is a highly context-specific and nuanced and responsive thing whose rightness could not be captured in a description that fell short of the artistic" (Nussbaum 1990a, p. 154). She offers that by reading with "moral attention," readers "become more responsive to [their] own life's adventure, more willing to see and to be touched by life" (Nussbaum 1990a, p. 162). Her argument, in essence, is that literature speaks to us: "It speaks about us, about our lives and choices and emotions, about our social existence and the totality of our connections" (Nussbaum 1990b, p. 171). William Prather considers Suttree a novel of moral value, stating it "is a novel about learning how to stay afloat, a metaphysical manual describing how to live in the river of life" (Prather 1995, p. 106). Richard Marius extends this argument, offering that Suttree's story exemplifies the human effort to transcend death while still alive: "[t]o transcend death, we must meet it head-on, savor all its horrors, understand

12 Bell explains how this water-bearer recalls the water-bearer earlier in the novel for whom, Suttree imagines, the men at a past banquet wait (McCarthy [1979] 1992, p. 136). 
its finality, and live our lives in that understanding." He continues, "[t]he names we find in McCarthy's pages are like epitaphs, tombstones to dead times" (Marius 1995, p. 5).

Furthermore, it is Sartre's conception of literature-specifically prose-that "the writer has chosen to reveal the world and particularly to reveal man to other men so that the latter may assume full responsibility before the object which has been laid bare" (Sartre 1993, p. 15). In Suttree's case, the object laid bare is life itself, and what is found in this revelation is life's dual character of meaninglessness and utter responsibility to fill the void of meaning for oneself. As Marius asserts, "the seriousness of life has no final meaning, no ultimate, transcendent goal. For McCarthy meaning exists day by day by the fact that we keep on living. If we choose to live, that choice in itself is our meaning" (Marius 1995, p. 15). In Suttree's progression from local derelict to departing artist, he exemplifies for readers and all humans the fortitude to take control of one's life and lead oneself in the direction of full responsibility and potential.

Literature and philosophy share the core value that is human life. Literature approaches life to expand human connections, promote understanding of people and culture, and perpetuate the beauty and diversity of language. Philosophy approaches life to remind of the ancient mysteries and problems of existence, perpetuate curiosity for those mysteries and problems, and posit potential explanations and solutions. Consequently, the merging of the two humanities infuses emotion and poetry into philosophy and intensifies the overall significance of literature. In this paper, I observed an instance in which philosophy informs literature, particularly how Sartre's existentialism informs the novel Suttree. Similarly, I demonstrated how literature illuminates philosophy, specifically how we find in Suttree's story a reflection of human existence's most serious questions and issues, an attempt to answer those questions, and a means to resolve those issues. Furthermore, I revealed how literature exposes the complexity of philosophical problems and the nuances of individual situations more than philosophy alone does. In Suttree, the problem of morality becomes more than a question of what is right: it becomes a question of what is right in these circumstances and with these potential consequences. The problem of identity becomes more than a question of who Suttree is: it becomes a question of who he wants to be and how he will become so. McCarthy marries and blends literature and philosophy into a form in which both are not easily separable; thus, Suttree as literature-with all the emotion, humor, and conflict it contains-engages with the philosophical questions of identity, freedom, and responsibility on a personal, unique level; and Suttree as philosophy-with its intuition that there is a moral and purpose to life, and its insistence on discovering that moral and purpose- - follows one man's existential quest to find himself. Through this synthesis, literature and philosophy achieve their greatest impact on readers and Suttree becomes at once a theatrical show, a painting of 50s urban Tennessee, and a room for meditation upon the mysteries of life and the urgency of identity.

My existential exploration of Suttree reveals the possibilities of philosophical, and existential, criticism in McCarthy's works. While I expounded the existential and philosophical foundation of Suttree, the same should be done for all of McCarthy's other works. Furthermore, I have laid the groundwork for a future and complex project to further synthesize Sartre's existentialism-including his concepts of being, nothingness, bad faith, freedom, responsibility, etc.-with McCarthy's works to capture the breadth of existential material in his stories and thereby relay the significance of this philosophy to human existence. Doing so will give Sartre's philosophy motion and clarity and enrich the system of unifying knowledge, theory, and criticism of McCarthy's fiction. Especially with McCarthy's belief that good writers "deal with issues of life and death," an existential analysis of his works gives ample insight into how to live responsibly, maintain an honest awareness of the nearness and importance of death, and avoid a self-negating attitude under the pressure of this nearness (Woodward 1992, p. 28).

Conflicts of Interest: The author declares no conflict of interest.

\section{References}

Arnold, Edwin T. 1999. Naming, Knowing and Nothingness: McCarthy's Moral Parables. In Perspectives on Cormac McCarthy, rev. ed. Edited by Edwin T. Arnold and Dianne C. Luce. Jackson: University Press of Mississippi, pp. $45-69$. 
Bell, Vereen M. 1983. The Ambiguous Nihilism of Cormac McCarthy. The Southern Literary Journal 15: 31-41. Bell, Vareen M. 1988. The Achievement of Cormac McCarthy. Baton Rouge: Louisiana State University Press.

Canfield, J. Douglas. 2001. Crossing from the Wasteland into the Exotic in McCarthy's Border Trilogy. In A Cormac McCarthy Companion. Edited by Edwin T. Arnold and Dianne C. Luce. Jackson: University Press of Mississippi, pp. 256-69.

Cooper, Lydia R. 2013. 'The Sculptor's Art': Mystery and the Material Body in Suttree. In You Would Not Believe What Watches: Suttree and Cormac McCarthy's Knoxville. Edited by Rick Wallach. Baton Rouge: Louisiana State University Press, pp. 190-97.

Cosper, Dale, and Ethan Cary. 1996. Suttree and L'Étranger: The Hounds of Gnosticism. In Studies on Lucette Desvignes and the Twentieth Century. vol. 6, pp. 155-76.

Giacometti, Alberto. 1961. L'Homme Qui Marche. Pittsburgh: Bronze Sculpture, Carnegie Museum of Art.

Guinn, Matthew. 2000. Ruder forms survive: Cormac McCarthy's atavistic vision. In Myth, Legend, Dust: Critical Responses to Cormac McCarthy. Edited by Rick Wallach. Manchester: Manchester University Press, pp. 108-15.

Holloway, David. 2002. The Late Modernism of Cormac McCarthy. Westport, Connecticut: Greenwood Press.

Jarrett, Robert L. 1997. Cormac McCarthy. New York: Twayne Publishers.

Josyph, Peter. 2010. Suttree's War of the Worlds: High Noon in Knoxville. In Adventures in Reading Cormac McCarthy. Lanham: The Scarecrow Press.

Luce, Dianne C. 2009. Reading the World: Cormac McCarthy's Tennessee Period. Columbia: University of South Carolina Press, pp. 194-270.

Longley, John Lewis, Jr. 1985. Suttree and the Metaphysics of Death. The Southern Literary Journal 17: 79-90.

Marius, Richard. 1995. Suttree as Window into the Soul of Cormac McCarthy. In Sacred Violence: A Reader's Companion to Cormac McCarthy. Edited by Wade Hall and Rick Wallach. El Paso: Texas Western Press, pp. 1-15.

McCarthy, Cormac. 1992. Suttree. New York: Vintage International.

McCarthy, Cormac. 1992. Blood Meridian, Or the Evening Redness in the West. New York: Vintage International.

McCarthy, Cormac. 2015. The Gardener's Son. New York: HarperCollins.

McCarthy, Cormac. 1960. A Drowning Incident. The Phoenix 1: 3-4.

Nussbaum, Martha C. 1990a. 'Finely Aware and Richly Responsible': Literature and the Moral Imagination. In Love's Knowledge: Essays on Philosophy and Literature. Edited by Martha C. Nussbaum. New York: Oxford University Press, pp. 148-67.

Nussbaum, Martha C. 1990b. Perceptive Equilibrium: Literary Theory and Ethical Theory. In Love's Knowledge: Essays on Philosophy and Literature. Edited by Martha C. Nussbau. New York: Oxford University Press, pp. 168-94.

Prather, William. 1995. Absurd Reasoning in an Existential World: A Consideration of Cormac McCarthy's Suttree. In Sacred Violence: A Reader's Companion to Cormac McCarthy. Edited by Wade Hall and Rick Wallach. El Paso: Texas Western Press, pp. 103-14.

Robinson, Forrest G. 2003. 'Everything's Interesting': Cormac McCarthy and the Social Construction of Reality. Arizona Quarterly 70: 87-127. [CrossRef]

Sartre, Jean-Paul. 1956. Being and Nothingness. Translated by Hazel E. Barnes. New York: Washington Square Press, First published 1943.

Sartre, Jean-Paul. 1993. What is Literature? (1948). Translated by Bernard Frechtman. New York: Routledge.

Sartre, Jean-Paul. 2004. Existentialism. (1946). In Basic Writings of Existentialism. Edited by Gordon Marino. New York: Modern Library, pp. 341-68.

Shelton, Frank W. 1990. Suttree and Suicide. Southern Quarterly 29: 71-83.

Woodson, Linda. 2013. Visual Rhetoric and Cognitive Identity in Suttree. In You Would Not Believe What Watches: Suttree and Cormac McCarthy's Knoxville. Edited by Rick Wallach. Baton Rouge: Louisiana State University Press, pp. 182-89.

Woodward, Richard B. 1992. Cormac McCarthy's Venomous Fiction. The New York Times, vol. 141, no. 48941. 28.

(C) 2017 by the author. Licensee MDPI, Basel, Switzerland. This article is an open access article distributed under the terms and conditions of the Creative Commons Attribution (CC BY) license (http://creativecommons.org/licenses/by/4.0/). 